\title{
Melanoma-Associated Antigen 1
}

National Cancer Institute

\section{Source}

National Cancer Institute. Melanoma-Associated Antigen 1. NCI Thesaurus. Code C104511.

Melanoma-associated antigen 1 (309 aa, 34 kDa) is encoded by the human MAGEA1 gene. This protein may play a role in embryonal development, tumor transformation, or tumor progression. 